Sains Malaysiana 49(3)(2020): 671-682

http://dx.doi.org/10.17576/jsm-2020-4903-22

\title{
Influence of Environmental Parameters on Microbiologically Influenced Corrosion Subject to Different Bacteria Strains
}

(Pengaruh Parameter Persekitaran ke atas Subjek Kakisan Pengaruh Mikrob kepada Strain Bakteria Berbeza)

\author{
Muhammad Khairool Fahmy Mohd Ali, Mardhiah Ismail, Akrima Abu BaKar, Norhazilan Md. Noor, \\ NORDIN YAHAYA, LiBRiATI ZARDASTI* \& ABDUl RAHMAN MD. SAM
}

\begin{abstract}
Microbiologically influenced corrosion (MIC) is capable on weakening the metal's strength, eventually leads to pipeline leakage, environmental hazard and financial loss. Sulfate reducing bacteria (SRB) is the principal causative organism responsible for external corrosion on steel structures. To date, considerable works have been conducted in Malaysia on the mechanisms of SRB upon MIC on the marine environment instead of underground. Moreover, commercial bacteria strain represents local strain in terms of performance and behavior upon corrosion of steel structure is yet to be proven. Thus, this paper aims to investigate the influence of environmental parameters towards MIC in corroding pipeline. Two types of SRB strain were used designated as SRB ATCC 7757 (commercial) and SRB Sg. Ular (local strain) isolated from Malaysian soil. The behavior of both strains was critically compared by calculating the rate of corrosion upon carbon steel coupons in stipulated environmental parameters. Four influential parameters i.e. pH, temperature, salinity concentration and iron concentration were considered. Collected data presented and analyzed using graphical and statistical analysis, respectively. The results showed the difference of corrosivity between two SRB strains in terms of corrosion behavior upon the X-70 steel coupon. SRB Sg. Ular able to cause severe effects upon steel structure as compared to SRB ATCC 7757 due to its aggressiveness shown by the recorded metal loss data. Thus, future works related to MIC for local environment in particular, should not compromise with the type of SRB strains considered due to differences of performance of the microorganisms onto tested environment and materials.
\end{abstract}

Keywords: Environmental parameter; microbiologically influenced corrosion (MIC); pipeline; sulfate-reducing bacteria $(S R B)$

\section{ABSTRAK}

Kakisan Pengaruh Mikrob (MIC) akan melemahkan kekuatan logam, mengakibatkan kebocoran saluran paip, ancaman terhadap alam sekitar dan kerugian wang ringgit. Bakteria penurunan sulfat (SRB) merupakan organisma utama yang bertanggungjawab mengakibatkan kakisan luar terhadap struktur keluli. Di Malaysia khususnya, banyak kajian berkaitan mekanisma SRB terhadap MIC dalam persekitaran marin telah dijalankan, berbanding persekitaran bawah tanah. Kebanyakan kajian terdahulu menggunakan strain komersial untuk mengkaji mekanisma SRB kerana ia mudah didapati berbanding strain tempatan. Bagaimanapun, tiada kenyataan khusus yang bersetuju bahawa strain komersial secara praktiknya mampu mewakili strain tempatan sepenuhnya daripada segi penilaian prestasi dan perilaku. Dengan itu, kajian ini dijalankan bertujuan untuk mengkaji kesan SRB strain yang berbeza terhadap kadar kakisan logam. Kajian ini menggunakan dua jenis strain SRB iaitu strain komersial ATCC 7757 dan strain SRB tempatan yang diambil dari Sungai Ular. Empat parameter persekitaran diambil kira dalam uji kaji ini iaitu pH, suhu, tahap kemasinan dan kepekatan iron. Data yang dikumpulkan telah dibentangkan dan dianalisis dengan menggunakan analisis grafik dan statistik. Keputusan kajian semasa menunjukkan perbezaan yang amat ketara antara kedua-dua strain SRB daripada segi tahap kakisan terhadap kupon keluli X-70. SRB Sg. Ular merupakan strain yang agresif dan ia berupaya mengakibatkan kesan yang lebih teruk terhadap struktur keluli berbanding SRB ATCC 7757, ini dapat dibuktikan dengan jelas melalui data kehilangan logam yang direkodkan. Justeru, bagi mendapatkan ramalan kakisan yang tepat pada masa hadapan, kerja-kerja yang berkaitan MIC khususnya tidak dipandang remeh, terutama berkaitan pemilihan organisma yang ingin digunakan.

Kata kunci: Bakteria penurunan sulfat (SRB); kakisan pengaruh mikrob (MIC); parameter persekitaran; saluran paip

\section{INTRODUCTION}

Pipelines buried in soil are susceptible to various forms of corrosion both internally and externally; total elimination is impossible, yet it is controllable. Corrosion of underground pipelines is heavily influenced by the microbiologically influenced corrosion (MIC) activities (Sukla \& Misra 2002). According to Abdullah et al. (2014), MIC is not a new version of corrosion but the corrosion 
process influenced by the microorganism activity and its metabolism by-product. MIC easily attack critical areas on the underground pipeline in localized corrosion (AlAbbas et al. 2013). MIC can lead to structural failure or loss of containment, costly repairs, lost or contaminated products, environmental damage, risk to personnel and loss of public confidence. Various incidents involving MIC activity, e.g. pinhole leaks on Alaskan pipeline and in various segments on a newly installed oil and water pipeline in Lost Hills Oilfield (Strickland et al. 1996), as well as the water injection system operated by Petrolite Corporation (Agostini et al. 1996). These leak events have caused turmoil in the global oil market (Jacobson 2007). There are various microorganisms exist in the environment (Beech et al. 2000). Previous studies recognized Sulfate reducing bacteria ( $\mathrm{SRB}$ ) as the principal causative organism who countable for corrosion on steel structures buried underground, hence unexpected structure failures (Abdullah et al. 2014; Al-Jaroudi et al. 2011). According to Al-Abbas et al. (2013), SRB is reported as anaerobic bacteria; but manage to survive in aerobic until it becomes suitably anaerobic for them to produce. SRB expedites in bio-corrosion rate within the pipeline systems due to the continuous production of poisonous and corrosive hydrogen sulfide $\left(\mathrm{H}_{2} \mathrm{~S}\right)$ (Al-Abbas et al. 2013; Javaherdashti 2008). As the time of immersion is increased, the nutrients in the environments start to deplete, which may cause the microorganism starved and death. However, past research has reported that the starved SRB could survive in the nutrients deplete environment by using the elemental iron from the steel structure as the electron donor ( $\mathrm{Li}$ et al. 2018; Xu \& Gu 2011b).

To date, considerable studies on mechanisms of MIC due to SRB activity had been conducted worldwide and at several marine locations in Malaysia (Allison et al. 2008; Bakar et al. 2013; Fatah et al. 2013; Kakooei et al. 2012; Sahrani et al. 2008). However, the mechanism of SRB upon the corrosion in marine environment is the focus of the study, compared to underground and seabed environment; there is still a divergence of views on the mechanisms of microbial corrosion by SRB due to the existence of various genus/strains. Majority of past studies focuses on finding the influence of SRB upon the bacterial growth and corrosion rate trend without considering detailed information regarding the strain used i.e. DNA profile and detail analysis. Therefore, research incorporating microbial corrosion subject to specific bacterial strain for local environment is scarce in Malaysia. For example, studies incorporated frequently used commercialized strains due to bacteria availability and its simplicity during handling process. American Type Culture Collection (ATCC) is known as one of the largest companies providing commercialized strain (designation number: ATCC 7757, pure strain) with specific genus including Desulfovibrio vulgaris subsp. vulgaris. These commercialized SRB strain is preferably by previous research, rather than isolated SRB strain from local site. On the contrary, there is no solid evidence that shows commercialized SRB strain can simulate or represent the corrosivity of the isolated SRB strain from the local site.

Apparently, every genus of bacteria possesses specific criteria and performance in different environment in order to grow at a maximum rate (Rabus et al. 2006). Each bacterial species has a specific tolerance range for specific environmental factors. According to Xu et al. (2011a), the physical and nutritional elements are probably the significant factors influence the growth rate and activity of the microorganisms. Metabolism of SRB can be influenced by these factors most of the microorganisms are sensitive to changes in the environment. The $\mathrm{pH}$ of the environment plays a vital role in bacterial activity (Lv et al. 2016). Generally, most of SRB species grow best at $\mathrm{pH}$ ranging from 6.5 to 9.0. Thus, it is necessary to maintain the $\mathrm{pH}$ level within its prescribed control limits to ensure the best growth condition for SRB because SRB is capable to cause a great drop in $\mathrm{pH}$ level due to production of $\mathrm{H}_{2} \mathrm{~S}$ and it is corrosive to metallic structure. Temperature is one of the important microbial growth limiting factors in the petroleum reservoir ecosystem (Lv et al. 2016; Varjani \& Upasan 2017). It could influences microbial growth, ranging from extremely low temperature may cause inhabitation of cellular metabolic processes to extremely high temperatures. This will affect the protein constituents of the cell through thermal denaturation causing the death of the cell. The third important factors influence bacterial activity is salinity concentration in the environment ( $\mathrm{Lv}$ et al. 2016). SRB is unlikely to proliferate if the salinity concentration of water is more than approximately $7 \%$ (wt. \% of $\mathrm{NaCl}$ ) (Stott 2003). High salinity concentration environment obstruct microbial growth. Booth and Tiller (1968) showed the importance of iron sulfate (FeS) production on the rate of corrosion promoted by SRB. This corrosion rate is significantly higher for FeS environment, to prove the involvement in cathodic depolarization process. Solid FeS formation on the metal surface becomes cathodic site, where hydrogen evolution from electrons and protons may occur effortlessly than on metal surface (King \& Miller 1971).

Future research regarding modeling and sensitivity analysis can be misled by the dissimilarity of performance between commercialized strain and isolated SRB strain from local site. Unless existing and current study could prove that the performance and corrosivity of isolated bacteria strains rely solely on environmental parameters is comparable to the commercialized strain in terms of corrosion rate, thus there is no ideal reason to emphasis on using the local SRB strain in future research. Therefore, strong empirical evidence is crucial for reaffirmation of that statement. Hence, a parametric study subject to MIC rate and the corrosivity between commercialized and local SRB strain based on one-factor-at-a-time (OFAT) approach under a controlled environment is crucial. Current study findings may show the discrepancies between the commercialized and local SRB strain isolated from underground in terms of bacteria metabolism and initiation or/and acceleration of corrosion at the early stage upon 
stipulated parameters. An accurate estimation of corrosion rate is essential in estimating corrosion allowances for structural designs, planning for inspections and scheduling maintenance (Wang et al. 2003). Thus, this work investigates the influence of environmental parameters (e.g. $\mathrm{pH}$, temperature, salinity concentration and iron concentration) towards MIC, specifically due to SRB presence and its microbial activity.

\section{MATERIALS AND METHODS}

\section{BACTERIA}

This study emphasis on two different sources of SRB with the same genus of Desulfovibrio vulgaris or formerly known as Desulfovibrio desulfuricans. The commercialized SRB strain purchased from American Type Culture Collection (ATCC) and the isolated SRB was from soil sample near the natural gas transmission line near Sungai Ular, Pahang; they were named as SRB ATCC 7757 and SRB Sg. Ular, respectively. Severe corrosion problem related to MIC due to presence of SRB around the Sg. Ular site have been reported previously (Othman 2015). The process of isolation of $\mathrm{Sg}$. Ular sample to obtain the single colony of Desulfovibrio vulgaris completed by a certified laboratory.

\section{CORROSION SPECIMEN}

Low carbon steel of grade API 5L X-70 (97.093\% of Iron, $0.078 \%$ of Carbon, $1.670 \%$ of Manganese, $0.150 \%$ of Nickel, $0.012 \%$ of Phosphorus, $0.300 \%$ of Silicon, $0.023 \%$ copper, $0.275 \%$ of chromium, $0.110 \%$ of titanium and $0.002 \%$ sulfur) coupons with dimension of $20 \mathrm{~mm} \times 10$ $\mathrm{mm} \times 5 \mathrm{~mm}$ were used as test material. All carbon steel coupons used in this study were prepared according to the ASTM standards and past research (Ali et al. 2016; ASTM G1-72 1993; ASTM G1-90 1999).

\section{PREPARATION AND PREFERABLE GROWTH MEDIA}

Both strains were cultivated in three different growth media for sulfate reducers such as Modified Baar 1249, Postgate $\mathrm{B}$ and Postgate $\mathrm{C}$ media. The chemical compositions of media, procedure for media preparation and inoculation process are similar as applied in previous research (Ali et al. 2017; Ismail et al. 2014). It is worth mentioning that the suitable growth medium applied in this study were chosen based on the experimental testing conducted in previous work (Ismail et al. 2015, 2014). It recommends culturing SRB ATCC 7757 and SRB Sg. Ular in Modified Baar 1249 and Postgate C media, respectively; hence, method used in this study.

\section{WEIGHT LOSS MEASUREMENT}

The immersion test had been carried out by exposing the metal coupons for 30-days in four different environments: Modified Baar's media without SRB (Control - ATCC),
Modified Baar's media with presence of SRB ATCC 7757, Postgate C media without SRB (Control - Sg. Ular), and Postgate C media with presence of SRB Sg. Ular. All metal coupons were retrieved from the anaerobic vials on weekly basis up to day-30 (day-7, 14, 21, and 30). At the end of immersion period, the metal coupons were cleaned by using Clarke's solution according to ASTM G1-03 (2011) and the corrosion rate was calculated based on the weight loss technique as applied in previous research (Ali et al. 2017).

\section{MICROSCOPY OBSERVATION}

Field Emission Scanning Electron Microscopy (FESEM) (model Supra 35VP) was used to observe biofilm layer and corrosion products formation on the surface of metal coupons. FESEM examination was divided into categories including the observation of: undisturbed API 5L X70 carbon steel surface, API 5L X70 carbon steel coupon exposed to culture media with presence of SRB (ATCC 7757 and Sg. Ular). All samples were prepared at condition of $\mathrm{pH} 7.5$ and incubated at $37^{\circ} \mathrm{C}$. The coupon was retrieved on day-30 and the sample for microscopic observation was performed according to the method applied based on previous research (Ali et al. 2017).

\section{ENVIRONMENTAL PARAMETERS TESTING}

In present study, four types of environmental parameters were chose in order to investigate the influence of $\mathrm{pH}$, temperature, salinity concentration and iron concentration on the rate of MIC process by considering two types of SRB strain. The effect of MIC activity were monitored by the corrosion rate of the metal coupons. The standard $\mathrm{pH}$, temperature, salinity concentrations and iron concentration in current research was set at $7.5,37^{\circ} \mathrm{C}, 100 \%$ concentration and $100 \%$ concentration, respectively. The recorded temperature for buried pipeline is lower than $70^{\circ} \mathrm{C}$. Therefore, temperature range from $0^{\circ} \mathrm{C}, 20^{\circ} \mathrm{C}, 37^{\circ} \mathrm{C}$ and $60^{\circ} \mathrm{C}$ was set in current experimental work in order to investigate its effect on the rate of corrosion. The chemical composition of magnesium sulfate $\left(\mathrm{MgSO}_{4} \cdot 7 \mathrm{H}_{2} \mathrm{O}\right)$ and ammonium iron (II) sulfate $\left(\mathrm{NH}_{4}\right)_{2} \mathrm{Fe}\left(\mathrm{SO}_{4}\right)_{2}$ represent the salinity and iron elements in the growth media, respectively. Salinity concentration and iron concentration were diversified in the range of $0 \%$ to $100 \%$ for the mixture of the media in order to investigate the influence of both parameters upon corrosion growth rate. Salinity concentration for both SRB strains varied depending on the composition of $\mathrm{MgSO}_{4} \cdot 7 \mathrm{H}_{2} \mathrm{O}$ in the media. As in $1 \mathrm{~L}$ of Modified Baar's and Postgate C media contains 4.096 $\mathrm{g}$ and $0.060 \mathrm{~g}$ of $\mathrm{MgSO}_{4} .7 \mathrm{H}_{2} \mathrm{O}$, respectively. Meanwhile, the composition of $\left(\mathrm{NH}_{4}\right)_{2} \mathrm{Fe}\left(\mathrm{SO}_{4}\right)_{2}$ in $1 \mathrm{~L}$ of Modified Baar's and Postgate $\mathrm{C}$ media is $0.672 \mathrm{~g}$ and $0.004 \mathrm{~g}$, respectively. Therefore, the variation of salinity concentration and iron concentration was designated every $25 \%$ for Modified Baar's and $50 \%$ for Postgate C media. The selected parameters with its range value of use in this study tabulated in Table 1. Parametric study based on one- 
factor-at-a-time (OFAT) approach was performed on both SRB strains. The concept of OFAT stated that only one parameter varied at a time while other parameters are fixed and the duration for OFAT testing was 30 days.

\section{RESULTS AND DISCUSSION}

\section{MICROSCOPIC OBSERVATION}

Figure 1 illustrates the FESEM micrograph image with Energy Dispersive X-ray Spectroscopy (EDS) spectra for undisturbed, exposed to SRB ATCC 7757 and SRB Sg. Ular onto API 5L X-70 carbon steel coupon surface, respectively. Based on the EDS result, high peak of iron (Fe) and low peak of carbon (C) was observed; this result proved the metal coupon used is low in carbon content. The EDS spectra results show difference in distribution of corrosion product adhered onto the coupon surface. After exposed to SRB Sg. Ular, the corrosion products on the coupon surface shows high peak of S and Fe compared to coupon surface exposed to SRB ATCC 7757 (Figure 1). Both Fe and $\mathrm{S}$ components were reported as essential components in SRB growth. The high amount of sulfur in the solution allows extensive activity of microbial during the incubation period. SRB is capable to reduce sulfate and other oxidized sulfur compounds to a corrosive and toxic $\mathrm{H}_{2} \mathrm{~S}$. Therefore, higher sulfur component may result in higher corrosion tendency on the steel structure. In addition, most of the EDS spectrum result shows the presence of high peak of oxygen $(\mathrm{O})$ element, which is probably due to the corrosion product formation from the oxide or hydroxide group and might be due to the exposure to oxygen during handling and cleaning process (Ali et al. 2017).

The morphologies for both strains are comma shapes, vibrio similar with Desulfovibrio sp. SRB, with the cells' size were approximately 1.5 to $2.0 \mu \mathrm{m}$ in accordance with previous study (Abdullah et al. 2014). However, physical observation exposed a slight difference in bacteria length, whereby SRB ATCC 7757 was slightly shorter than SRB Sg. Ular of $1.99 \mu \mathrm{m}$ and $2.59 \mu \mathrm{m}$, respectively (Ali et al. 2016).

\section{METAL WEIGHT LOSS OBSERVATION DUE TO BACTERIA ACTIVITY}

Figures 2 illustrates the progress of metal loss under influence of stipulated environmental parameters for both
SRB strains at day-30. Detail observation on metal loss represented by both graphical and statistical analysis. All coupons were considered uniform; hence, measurement of metal loss from different samples retrieved at different points of time was assumed to be correlated. After 30-days of incubation, most of the recorded metal loss in SRB Sg. Ular environment is higher compared metal loss exposed to SRB ATCC 7757. The highest recorded metal loss for SRB Sg. Ular is $0.028 \mathrm{~g}$ (at $\mathrm{pH} 7.5$ ) and SRB ATCC 7757 is $0.025 \mathrm{~g}$ (at $\mathrm{pH}$ 5.5) (Figure 2(D)). Dissolution rate of $\mathrm{H}_{2} \mathrm{~S}$ may increase at higher $\mathrm{pH}$ value (Cao et al. 2009). These results prove that SRB Sg. Ular could be more harmful and dangerous to steel structure compared to SRB ATCC 7757.

The influence of temperature towards metal weight loss of the steel coupon was illustrated in Figure 2(E). The results show only a minimal difference in metal loss value between two different $\mathrm{SRB}$ strains at respective temperature. Recorded metal loss at $0^{\circ} \mathrm{C}$ temperature shows the lowest value $(0.011 \mathrm{~g}$ for SRB Sg. Ular and $0.015 \mathrm{~g}$ for SRB ATCC 7757) because it is a less suitable temperature level for the microorganism to grow well and perform their activity as compared to other temperatures. Meanwhile, the highest metal loss value recorded for SRB ATCC 7757 (0.024 g) and SRB Sg. Ular $(0.026 \mathrm{~g})$ under influence of temperature is at $20^{\circ} \mathrm{C}$ and $37^{\circ} \mathrm{C}$, respectively. These results were in line with previous research that the suitable temperature for bacteria to grow rapidly and perform its activity actively is at temperature lower than $60^{\circ} \mathrm{C}$ (Angell \& Urbanic 2000).

Variation of parameter salinity and iron concentration shows metal loss recorded after exposure to SRB Sg. Ular is much higher as compared to SRB ATCC 7757 as shown in Figure 2(F) and 2(G). These results proved that higher percentage of salinity concentration and iron concentration with presence of SRB Sg. Ular in the environment will leads to higher metal loss. The metal loss difference between both SRB for salinity and iron concentration parameter are significantly observed. Both salinity and iron concentration are considered as important chemical components influence the formation of biofilm (Truong et al. 2010). Within biofilms structure, the convection of compounds is blocked and consequently mass transfer to the cells often limits conversion rates, thus develop various microenvironments that may facilitate the activity of microorganism (Santegoeds et al. 1998). This study shows most of the recorded metal loss with presence of SRB Sg.

TABLE 1. Summary of environmental parameters for laboratory test

\begin{tabular}{|c|c|}
\hline Parameter & Range \\
\hline $\mathrm{pH}$ & $5.5,6.5,7.5,8.5$ and 9.5 \\
\hline Temperature $\left({ }^{\circ} \mathrm{C}\right)$ & $0,20,37$ and 60 \\
\hline $\begin{array}{l}\text { Salinity concentration (varies amount of } \mathrm{MgSO}_{4} \cdot 7 \mathrm{H}_{2} \mathrm{O} \text { in the } \\
\text { media) }(\%)\end{array}$ & $\begin{array}{l}\text { Modified Baar's media : } 0,25,50,75 \text {, and } 100 \text { Postgate C } \\
\text { media: } 0,50 \text {, and } 100\end{array}$ \\
\hline $\begin{array}{l}\text { Iron concentration (varies amount of }\left(\mathrm{NH}_{4}\right)_{2} \mathrm{Fe}\left(\mathrm{SO}_{4}\right)_{2} \text { in the } \\
\text { media) }(\%)\end{array}$ & $\begin{array}{l}\text { Modified Baar's media: } 0,25,50,75 \text {, and } 100 \text { Postgate } C \\
\text { media: } 0,50 \text {, and } 100\end{array}$ \\
\hline
\end{tabular}



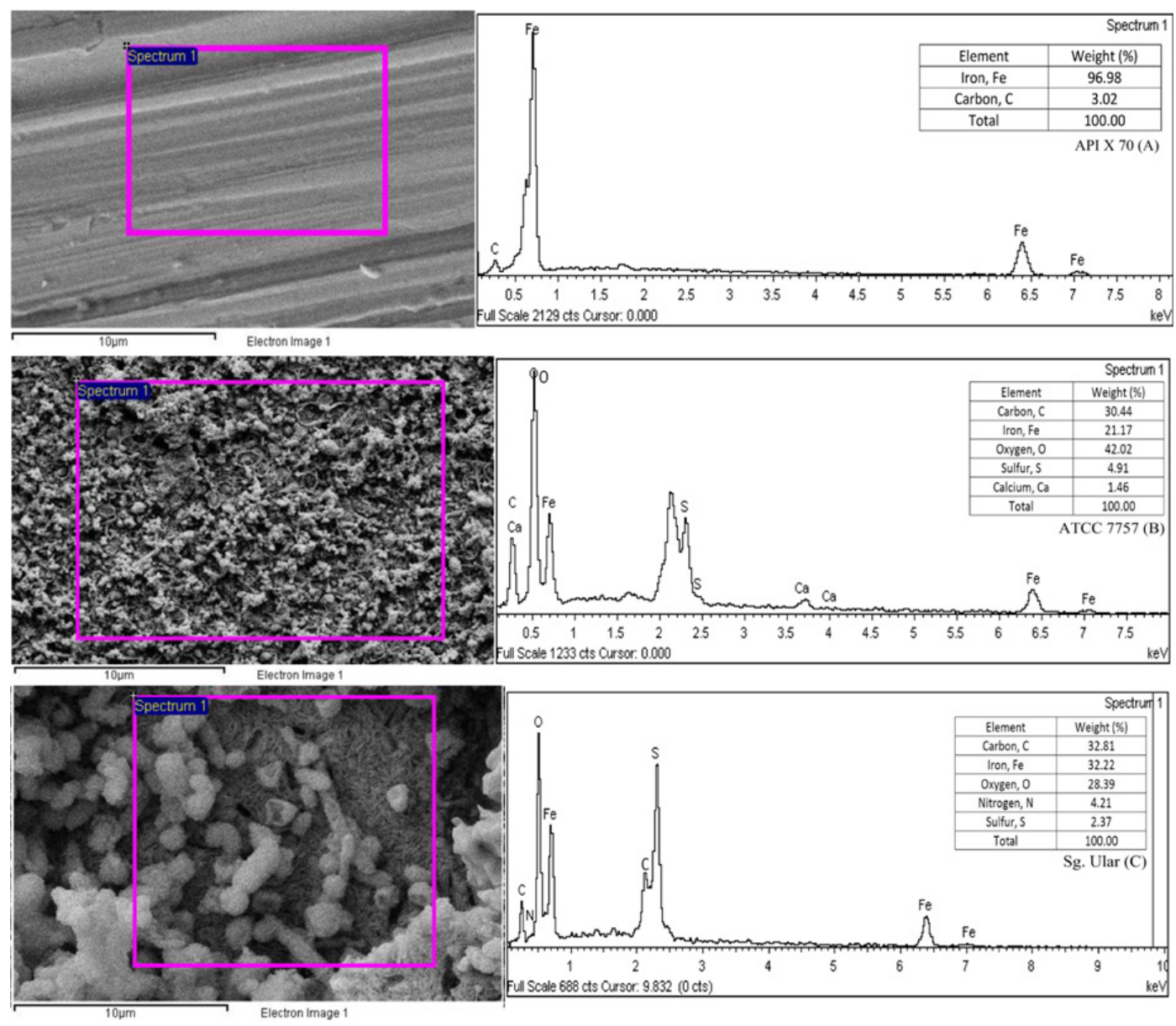

FIGURE 1. FESEM micrograph image with EDS spectra of (A) undisturbed carbon steel coupon, (B) SRB ATCC 7757 and (C) SRB Sg Ular biofilm formed at day-30

Ular under stipulated environment is much higher as compared to metal loss recorded when exposed to SRB ATCC 7757. Therefore, SRB Sg. Ular is much more active and reacts aggressively towards the environment and metal coupon as compared to SRB ATCC 7757.

\section{FACTORIAL ANALYSIS ON METAL WEIGHT LOSS}

The results were analyzed statistically by using Analysis of Variance (ANOVA) test. A full factorial design is a method to study the effect of each factor on the response variable, as well as the effects of interactions between factors on the response variable. ANOVA-test is simply comparing the means to see if they are significantly different between each other. The null hypothesis were set as there is no difference between the means; change in the intensity of independent parameters will not affect the metal weight loss, whereas the alternative hypothesis is vice versa. Seven null hypotheses were assumed for all variations of environmental parameters as follows: $H 1$ : SRB strain does not affect metal loss; $H 2$ : the parameter tested does not affect metal loss; H3: the time of sample exposure does not affect metal loss; H4: SRB strain upon each parameter influenced metal loss pattern; H5: SRB strain at different time of exposure does not affect the metal loss; H6: each parameter tested at different time exposure does not affect the metal loss; and H7: SRB strain with parameter tested at different time exposure does not affect the metal loss pattern.

In general, the factorial analysis by ANOVA-test has provided an explicit explanation of the governance of a few independent variables, namely SRB strain, variation of environmental parameter tested and time of exposure on metal weight loss. Findings indicate that other parameters shown their dominancy on metal loss progress caused by different types of SRB strains except for the temperature parameter. This is proven by the $p$-value of 0.6746 obtained from ANOVA testing higher as compared to $95 \%$ confidence interval as summarized in Table 2 . In addition, findings proved that different SRB strain reacts differently to variation of $\mathrm{pH}$, salinity concentration and iron concentration, consequently influence the rate of metal loss. On the other hand, the change of temperature does not significantly influence metal loss, except for certain levels/value of intensity. Therefore, present research proved that different SRB strains i.e. SRB ATCC 7757 and $\mathrm{SRB} \mathrm{Sg}$. Ular, undergo significant difference in metal loss recorded under different stipulated environment throughout the study. 

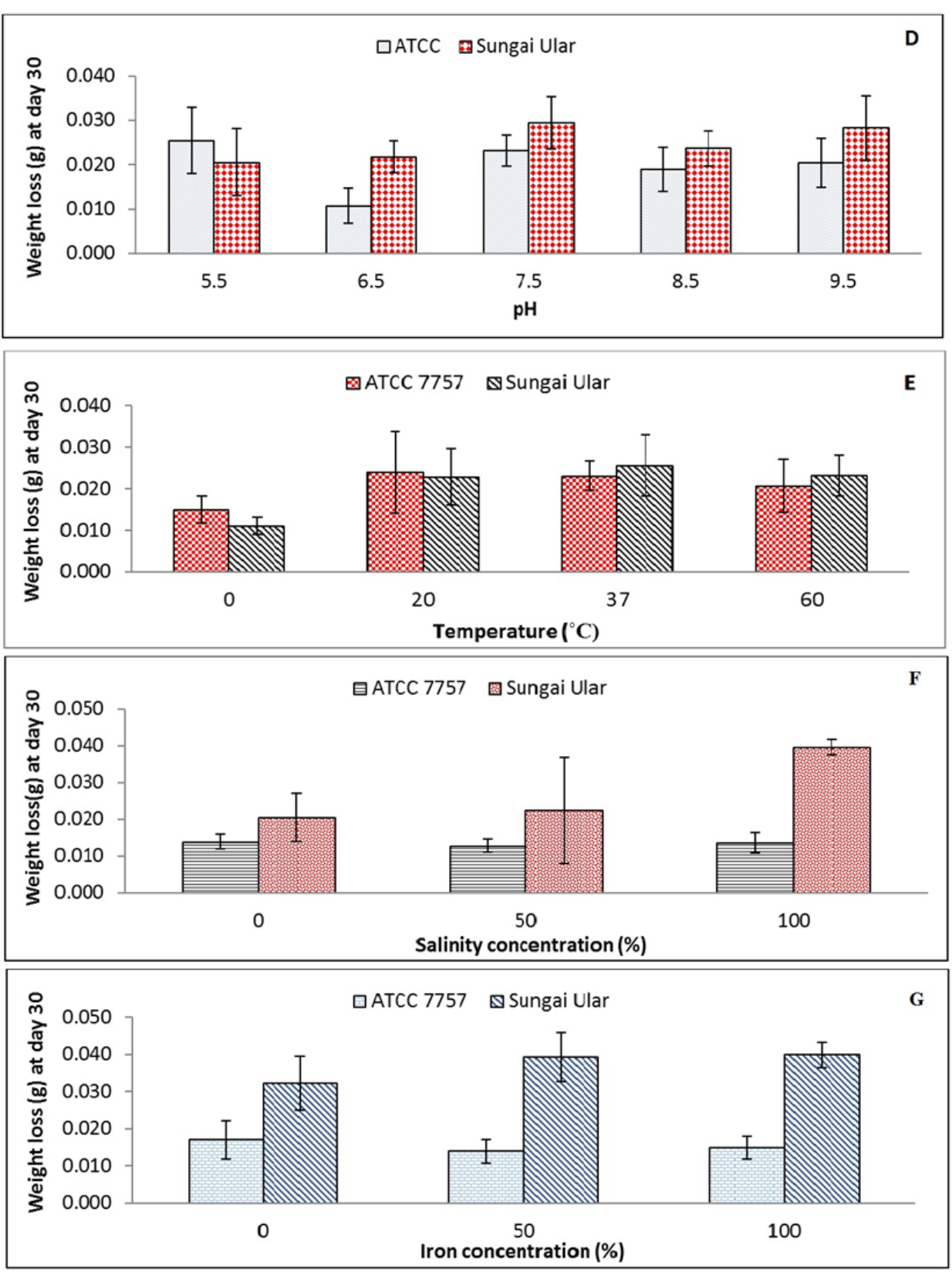

FIGURE 2. Metal loss of steel coupon after exposure to SRB ATCC 7757 and SRB Sg. Ular for 30-day under influence of (D) pH, (E) temperature, $(\mathrm{F})$ salinity and $(\mathrm{G})$ iron concentration

TABLE 2. Summary of ANOVA result for metal weight loss

\begin{tabular}{lccc}
\hline Factorial analysis & Environmental parameters & Value & Result \\
\hline $\mathrm{p}$-value & $\mathrm{pH}$ & 0.0020 & Positive \\
& Temperature & 0.6746 & Negative \\
& Salinity & 0.0028 & Positive \\
Fcalculated & Iron concentration & 0.0055 & Positive \\
& $\mathrm{pH}$ & 5.6590 & Positive \\
& Temperature & 0.5120 & Negative \\
& Salinity & 6.1190 & Positive \\
\hline
\end{tabular}




\section{CORROSION RATE OBSERVATION}

The influence of $\mathrm{pH}$ value on the corrosion progress due to SRB ATCC 7757 and SRB Sg. Ular activity are illustrated in Figure 3(H) and 3(I), respectively. Both graphs displayed a similar pattern where the rate of corrosion was extremely high at the beginning of the experiment and drastically reduced to almost half starting from second retrieval onwards. Meanwhile, the corrosion rate under the influence of temperature for both SRB strains were illustrated in Figure $3(\mathrm{~J})$ and $3(\mathrm{~K})$, respectively. Throughout the incubation period, the corrosion rate pattern at temperature $20^{\circ} \mathrm{C}$ and $37^{\circ} \mathrm{C}$ were similar for both SRB strains, except at temperature $60^{\circ} \mathrm{C}$ during the first 7-days of incubation. Based on the graph, in terms of severity, the difference in corrosion rate for all retrievals is quite small between the SRB ATCC 7757 and Sg. Ular $\mathrm{SRB}$, except for the first 7-days. However, it is clearly shown that the corrosion rate recorded by SRB Sg. Ular under stipulated temperatures is much higher as compared to SRB ATCC 7757.

The third environmental parameter considered in this study is salinity concentrations and its effect towards the corrosion rate trend subject to SRB ATCC 7757 and SRB Sg. Ular activity, is shown in Figure 4(L) and 4(M), respectively. All variation of salinity content share a common corrosion rate pattern regardless of corrosion rate value throughout the exposure time. The corrosion rates recorded for SRB ATCC 7757 strain are more severe than SRB Sg. Ular during the 7-day and it is gradually decrease with time. The corrosion rate recorded is not significantly observed for SRB ATCC 7757; meanwhile SRB Sg. Ular shows a significant difference between the variations of salinity concentrations. Result indicates that in Sg. Ular sample, as the salinity concentration increases, the corrosion rate also increases. Final day (day-30) of retrieval is considered as the most stable state, it allows the assessment and comparison of the corrosion rate between both SRB strains. Last but not least, iron concentration explicitly produces consistent corrosion rate patterns regardless of its intensity. From the Figure $4(\mathrm{~N})$ and $4(\mathrm{O})$, the highest corrosion rate was recorded at the first retrieval for both SRB strains before gradually decreasing until the final retrieval (day-30). In addition, the result obviously illustrates that SRB Sg. Ular results in severe corrosion condition as compared to SRB ATCC 7757.

Figure 5(P) to 5(S) illustrated the graph of comparison in corrosion rate between sample with presence of SRB and control sample (absence of SRB) under stipulated environmental parameters. The results showed none of the corrosion rates exceeds the samples with presence of SRB. Furthermore, the findings confirmed that most of the $\mathrm{pH}$ levels tested except for acidic ( $\mathrm{pH}$ 5.5) environment, the corrosion rate of the carbon steel coupons react with SRB Sg. Ular, is much higher as compared to SRB ATCC 7757 (Figure 5(P)). Most species of Desulfovibrio grow best between the ranges of $\mathrm{pH} 5.5$ and 9.0. Previous study in oxygenated environment shown the mechanisms of acid corrosion, where most of the by-products produce through MIC activities are corrosive for carbon steel (Evan et al. 1973; Zhang et al. 2011). The amount of removed iron and the increment in $\mathrm{pH}$ value varies with the amount of sulfate reduction presence in the environment (White et al. 1996). $\mathrm{pH}$ is an essential parameter as the alkaline environment assists in microbial activity by increasing the production

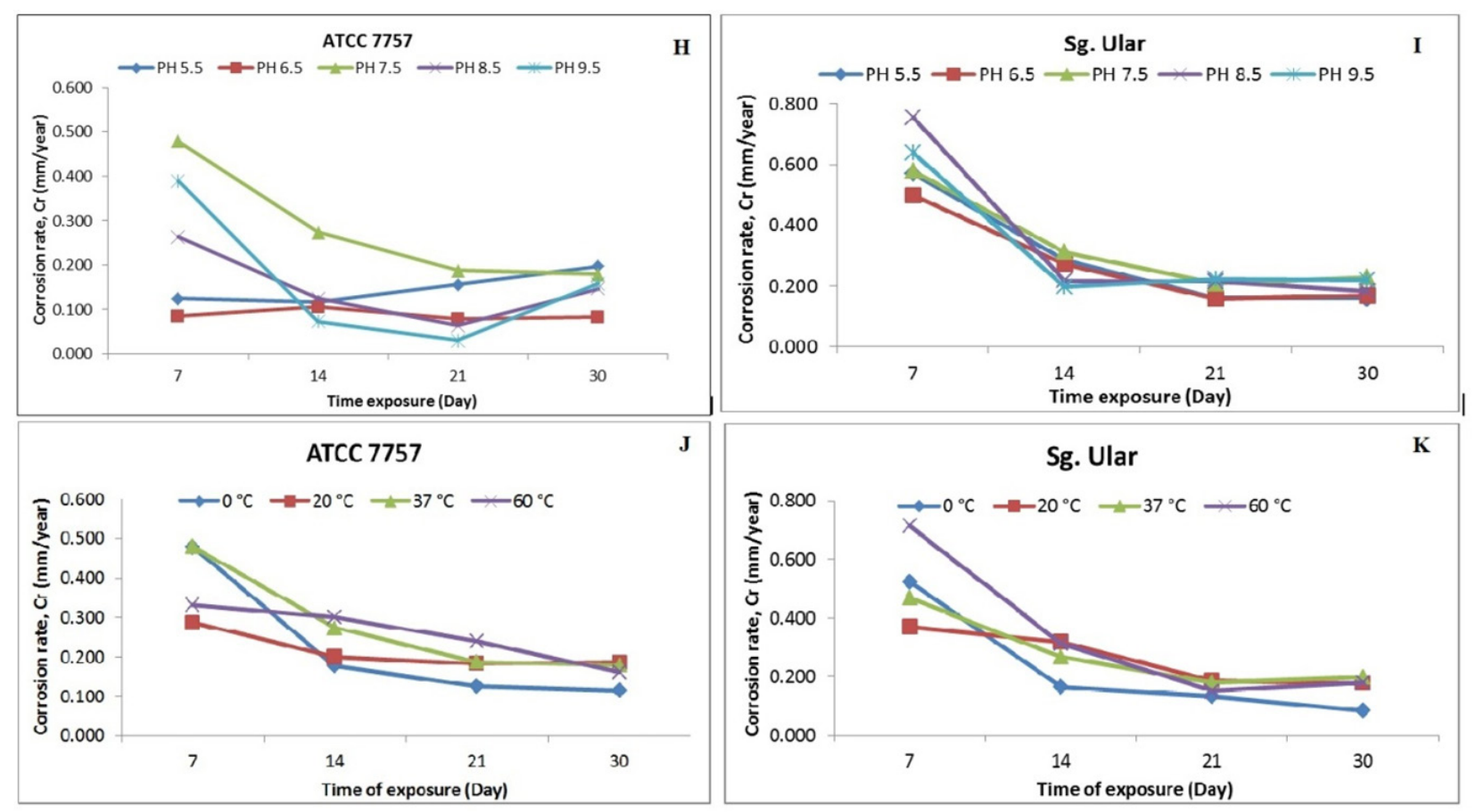

FIGURE 3. Graph of corrosion rate against day influenced of pH; (H) SRB ATCC 7757, (I) SRB Sg. Ular and temperature; (J) SRB ATCC 7757, (J) SRB Sg. Ular 


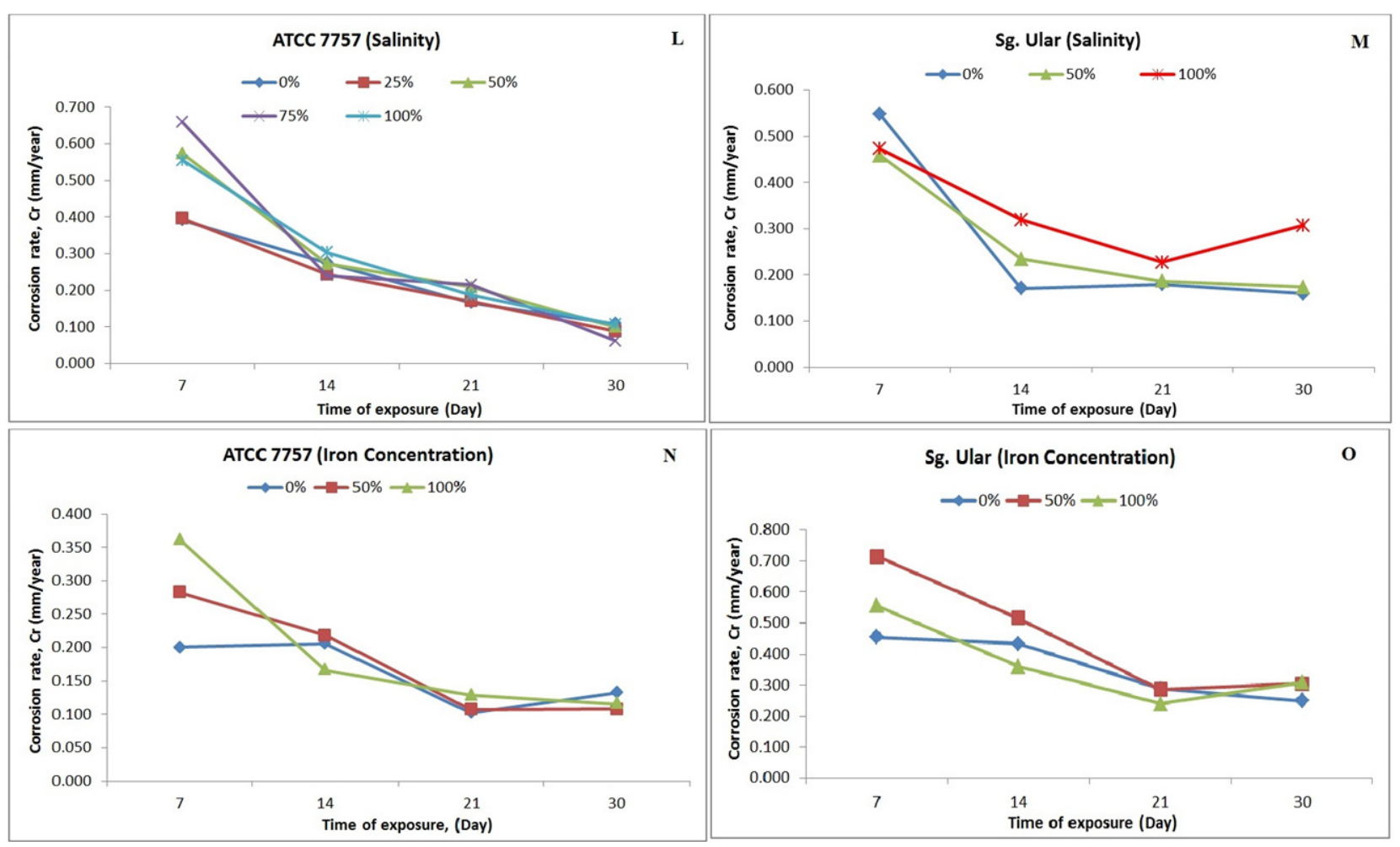

FIGURE 4. Graph of corrosion rate against day influenced of salinity; (L) SRB ATCC 7757, (M) SRB Sg. Ular and iron concentration; (N) SRB ATCC 7757, (O) SRB Sg. Ular

of corrosive metabolic product i.e. $\mathrm{H}_{2} \mathrm{~S}$. At higher level of $\mathrm{pH}$ value, the faster the rate of $\mathrm{H}_{2} \mathrm{~S}$ dissolution (Cao et al. 2009). Thus, corrosion rate of carbon steel is higher compared to lower $\mathrm{pH}$ level.

On the other hand, Figure 5(Q) illustrates a histogram of corrosion rate comparison between SRB ATCC 7757 and SRB Sg, Ular under stipulated temperature at day-30. After 30-days of incubation, result shows that at lower temperatures $\left(0^{\circ} \mathrm{C}\right.$ and $\left.20^{\circ} \mathrm{C}\right)$, the corrosion process by SRB ATCC 7757 activity is much higher compared to SRB Sg. Ular (Figure 5(Q)). Overall, the rate of corrosion on the carbon steel exposed to SRB activity at certain range of temperature is much higher as compared to the control samples. The results are in agreement with past studies as the SRB may expedite the rate of corrosion on the steel coupon. In addition, the difference of corrosion rate recorded between both $\mathrm{SRB}$ strains in stipulated temperature is rather small when compared to other parameters. Bacteria can barely survive at high temperature since most of the bacteria grow actively at temperature below $60^{\circ} \mathrm{C}$ (Angell \& Urbanic 2000). Furthermore, in extremely low temperature, bacteria require more dissolved organic material to match the growth rate observed in higher temperature (Kirchman et al. 2005). Figure 5(Q) clearly illustrate that the highest corrosion rate was recorded when the coupons were exposed to SRB activity at temperature of $20^{\circ} \mathrm{C}$ and $37^{\circ} \mathrm{C}$. The formation of rust and the depletion of essential nutrients in a medium have restricted the progress of corrosion onto the metal surface, hence resulting low in metal loss volume. At an optimum temperature, it is expected that the microorganisms, specifically SRB could produce abundance of corrosive by-product i.e. $\mathrm{H}_{2} \mathrm{~S}$.

Figure 5(R) illustrated histogram of corrosion rate particularly on day-30 under influenced of salinity concentration for SRB ATCC 7757 and Sg. Ular strains. It is clearly shown that variation of salinity concentration have low effects on the corrosion rate by SRB ATCC 7757, as the corrosion rate at all salinity concentration is approximately the same. In contrast, the corrosion rate by SRB Sg. Ular is highly influenced by the concentration of salinity present in the environment. However, there is only a small difference in corrosion rate recorded between the sample exposed to SRB Sg. Ular and the control sample (Sg. Ular) as shown in Figure 5(R). The Postgate C media itself is highly influence by salinity concentration therefore, it shows that salinity concentration has a significance effects towards the rate of corrosion upon the steel coupon specifically by SRB Sg. Ular. Meanwhile, Figure 5(S) shows variation in concentration of iron influences the corrosion rate for both SRB strains significantly. Nevertheless, influence upon corrosion rate by SRB Sg. Ular is extremely high as compared to SRB ATCC 7757 for all range of iron concentrations (Figure 5(S)). In addition, data of corrosion rate on the carbon steel for control sample of Postgate $\mathrm{C}$ media are higher compared to control sample of Modified Baar's medium as shown in Figure 5. Thus, it can be concluded that iron concentration has a significant effects on the rate of corrosion for both SRB strains. 


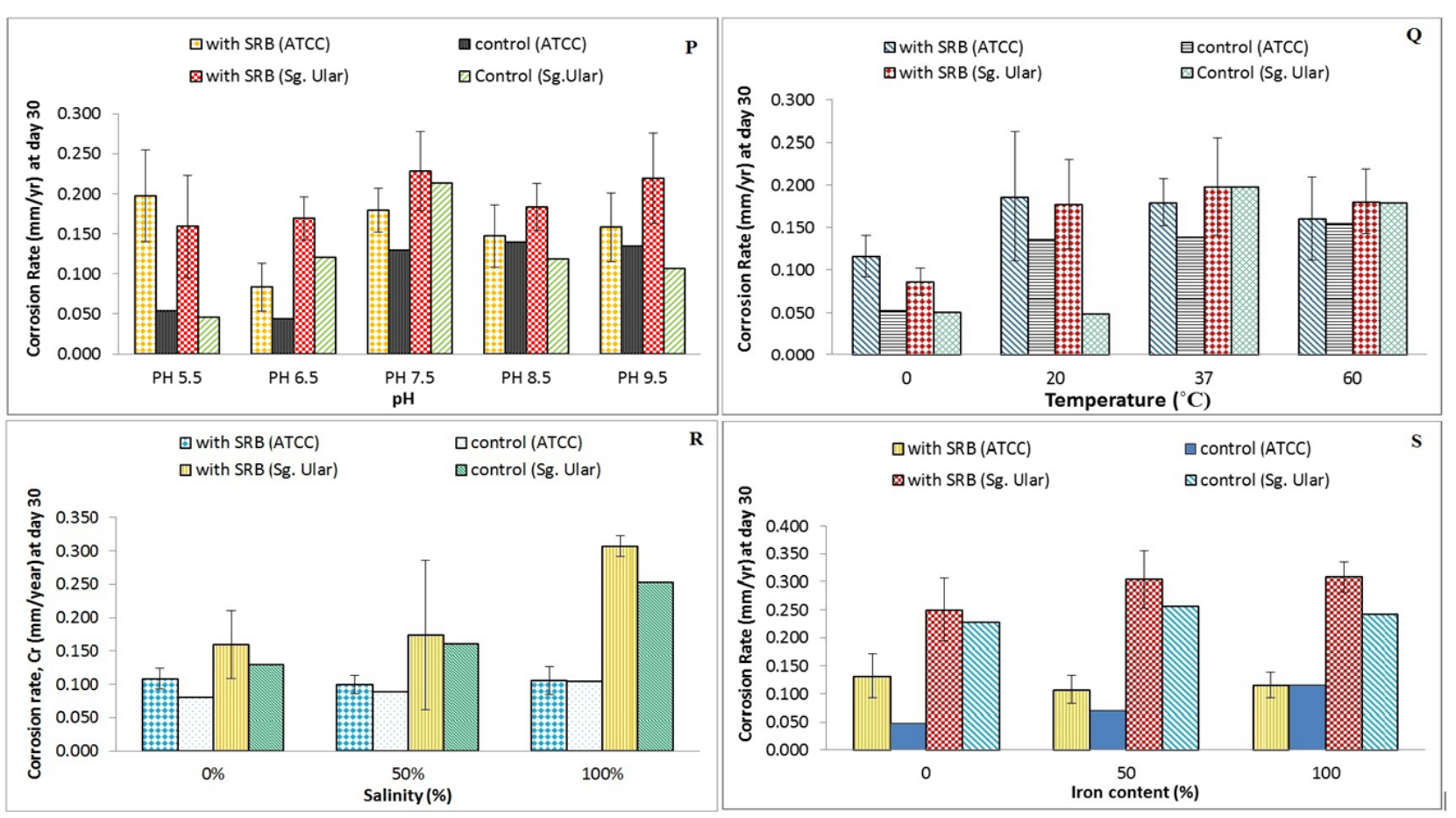

FIGURE 5. Corrosion rate of steel coupon after exposure to sample in the absence and presence of SRB ATCC 7757 and SRB Sg. Ular for 30-day under influence of $(\mathrm{P}) \mathrm{pH},(\mathrm{Q})$ temperature, $(\mathrm{R})$ salinity and $(\mathrm{S})$ iron concentration

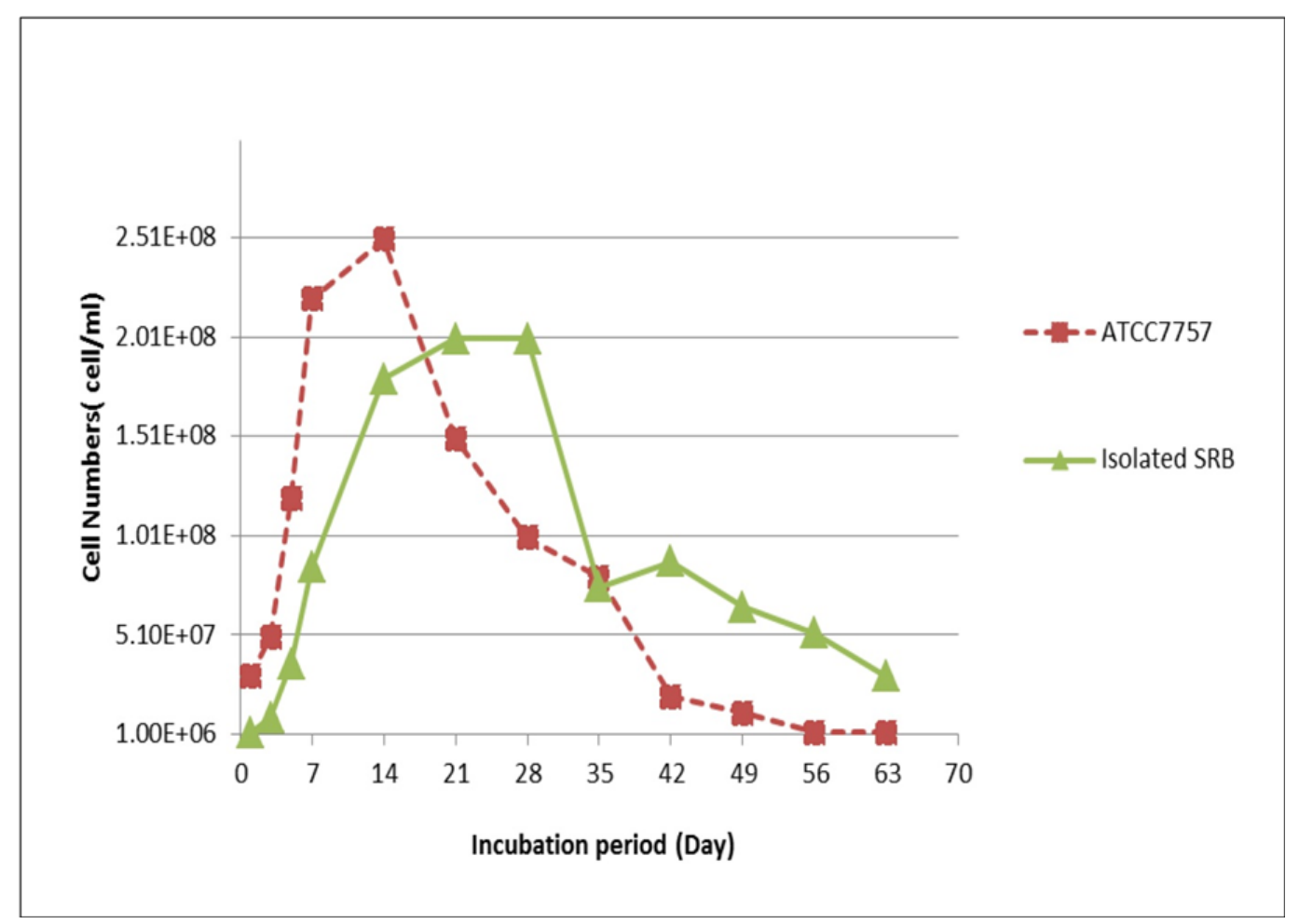

FIGURE 6. Growth curves of SRB ATCC 7757 and Sg. Ular (isolated SRB) incubated at $37^{\circ} \mathrm{C}$ for 60 days in anaerobic vials (Source: Abdullah, 2016) 
Based on the variation of salinity concentration and iron concentration as shown in Figure 5(R) and 5(S), respectively, the histogram clearly shows that the corrosion rate due to $\mathrm{SRB} \mathrm{Sg}$. Ular activity is much higher as compared to SRB ATCC 7757. Thus, salinity concentration and iron concentration are considered as the influential chemical components from the surrounding for microorganism activity and the formation of biofilm (Truong et al. 2010). In addition, specific bacteria growth curve is an important element when dealings with microbial corrosion. The growth of SRB in the limited containing culture medium consists of three stages for SRB growth, namely exponential phase, steady phase and dead phase. As illustrated in Figure 6, SRB ATCC 7757 achieved maximum growth on the day-14 as opposed to day-21 for SRB Sg. Ular. The numbers of active SRB ATCC 7757 start to decrease rapidly from day-14 to day-42. Meanwhile, SRB Sg. Ular exhibit a consistent and longer steady phase period starting from day-21 until day-28. The decline of bacterial numbers (dead phase) was only witnessed after day-28 until day-35. This exponential and steady phase of growth behavior might contribute towards the higher corrosion rate recorded by the Sungai Ular strain as compared to SRB ATCC 7757 (Abdullah 2016).

Furthermore, ANOVA analysis supports the graphical analysis where $p$-values for both parameters are far less than 0.05 (Table 2). Hence, the positive results may be due to dominant effect of those parameters towards corrosion rate of the carbon steel coupon. Generally, the patterns of corrosion rates under all stipulated parameters are quite similar, as it starts at the highest rate for the first retrieval and gradually decreasing until the final retrieval (day-30). Among the plausible explanation is because the higher corrosion rates in the beginning after short exposures are certainly due to the excessive production of corrosion product hydrogen sulfide $\left(\mathrm{H}_{2} \mathrm{~S}\right)$ through the microbial activity. As times goes by, the presence of iron sulphide (FeS) precipitation (Fonseca et al. 1997) and cell adhesion onto the surface of metal which enhanced by the surface hydrophobicity of the substrate; creating a mature biofilm formation onto the metal surface that could acts as a protective layer (passivating film) which contribute to the reduction of corrosion rate. Biofilms affect the interactions between the metal surfaces and the environment, not only in bio-deterioration processes e.g. MIC, but also in several biotechnological processes applied to material recovery and handling (Videla \& Herrera 2005).

\section{CONCLUSION}

In this study, the corrosion behavior on API 5L X70 carbon steel coupons were compared in detail between local isolated SRB strains (Sg. Ular) and commercialized SRB strains (ATCC 7757) under stipulated environment. The most important results marked are:

Even though the morphology results for both strains are quite similar, through the energy dispersive X-ray spectroscopy (EDS) observation, the sulfur content after exposure to SRB Sg. Ular activity is much higher as compared to SRB ATCC 7757. Through OFAT approach upon variation of environmental parameters, results showed that temperature has no significant influence on metal loss caused by SRB strain individually. Meanwhile, the parameter $\mathrm{pH}$, salinity concentration and iron concentration has a major effect upon metal loss, meanwhile iron content is considered as the least influential factor. Most of the recorded corrosion rate due to SRB Sg. Ular is much higher as compared to SRB ATCC 7757. Therefore, present research suggested that any research work incorporate modeling for microbial corrosion should be more specific and differentiate between the local and commercialized SRB strain due to the difference in aggressiveness and effects towards the environment and corrosion progress of the steel material/coupon.

In conclusion, from this study, SRB is proven to rapidly respond and easily adapt to harsh environmental changes vital for their survival (Mataqi \& Akbar 2013). Regardless of the amount of concentration and/or intensity, $\mathrm{pH}$, temperature, salinity concentration and iron concentration shows a significant effect on the SRB growth and corrosion rate of the steel coupon. Based on the graphical and statistical result, SRB Sg. Ular (local strain) results in severe corrosion and detrimental effect upon the carbon steel coupon as compared to commercialized SRB ATCC 7757.

\section{ACKNOWLEDGEMENTS}

The work was financially supported by Universiti Teknologi Malaysia through Grant No. GUP 03H49 and Zamalah Institutional Scholarship provided by Universiti Teknologi Malaysia. The authors gratefully acknowledge School of Civil Engineering and Environmental Laboratory UTM for the facilities provided.

\section{REFERENCES}

Abdullah, A. 2016. External Corrosion Growth for Buried Steel Pipeline in Environment Containing Sulfate Reducing Bacteria. Universiti Teknologi Malaysia (Unpublished).

Abdullah, A., Yahaya, N., Noor, N.M. \& Rasol, R.M. 2014. Microbial corrosion of API 51 X-70 carbon steel by ATCC 7757 and consortium of sulfate-reducing bacteria. Journal of Chemistry 2014: 130345.

Ali, M.K.F.M., Bakar, A.A., Noor, N.M., Yahaya, N., Ismail, M. \& Rashid, A.S. 2017. Hybrid soliwave technique for mitigating sulfate-reducing bacteria in controlling biocorrosion: A case study on crude oil sample. Environmental Technology 38(19): 2427-2439.

Ali, M.K.F.M., Yahaya, N., Bakar, A.A., Ismail, M., Zardasti, L. \& Noor, N.M. 2016. Corrosion of X-70 carbon steel pipeline subject to sulfate reducing bacteria. ARPN Journal of Engineering and Applied Sciences 11(21): 12643-12652.

Agostini, R.A. \& Young, R.D. 1996. A case history: Investigations of microbially influenced corrosion in a West Texas water flood microbiologically induced corrosion of oil and gas production system. NACE International Publications 1996: 122-127. 
Al-Abbas, F.M., Williamson, C., Bhola, S.M., Spear, J.R., Olson, D.L., Mishra, B. \& Kakpovbia, A.E. 2013. Influence of sulfate reducing bacterial biofilm on corrosion behavior of low-alloy, high-strength steel (API-5L X80). Journal of International Biodeterioration \& Biodegradation 78: 3442.

Al-Jaroudi, S., Ul-Hamid, A. \& Al-Gahtani, M. 2011. Failure of crude oil pipeline due to microbiologically induced corrosion. Corrosion Engineering, Science Technology 46(4): 568-579.

Allison, P.W., Sahar, R.N.R.R., Guan, O.H., Hain, T.S., Vance, I. \& Thompson, M.J. 2008. The investigation of microbial activity in an offshore oil production pipeline system and the development of strategies to manage the potential for microbially influenced corrosion. Paper No. 08651. NACE International: Corrosion 2008 Conference and Expo. pp. $1-17$

Angell, P. \& Urbanic, K. 2000. Sulfate reducing bacterial activity as a parameter to predict localized corrosion of stainless alloy. Corrosion Science 42: 897-912.

ASTM G1-03. 2011. Standard Practice for Preparing, Cleaning, and Evaluating Corrosion Test Specimens. ASTM International. Pennsylvania: American Society for Testing and Materials.

ASTM G1-90. 1999. Standard Practice for Preparing, Cleaning, and Evaluating Corrosion Test Specimens. ASTM International, Pennsylvania: American Society for Testing and Materials.

ASTM G1-72. 1993. Standard Recommended Practice for Preparing, Cleaning and Evaluating Corrosion Test Specimens. Annual Book of ASTM standards. Philadelphia: American Society for Testing and Materials.

Bakar, A.A., Noor, N.M., Yahaya, N., Rasol, R.M. \& Ali, M.K.F.M. 2013. The effect of Desulfovibrio vulgaris on the anaerobic corrosion of carbon steel in marine environment. 12th International UMT Annual Symposium (UMTAS2013). pp. 1-7.

Beech, I., Bergel, A., Mollica, A., Flemming, H.C., Scotto, V. \& Sand, W. 2000. Microbiologically influenced corrosion of industrial materials. Brite-Euram III Thematic Network ERB BRRT-CT98-5084 (Unpublished).

Booth, G.H. \& Tiller, A.K. 1968. Cathodic characteristic of mild steel in suspension of sulfate-reducing bacteria. Corrosion Science 8: 583-600.

Cao, J., Zhang, G., Mao, Z., Fang, Z. \& Yang, C. 2009. Precipitation of valuable metals from bioleaching solution by biogenic sulphides. Mineral Engineering 22: 289-295.

Evan, E., Chart, A. \& Skedgell, A.N. 1973. The coloured film on stainless steel. Transactions of the Institute of Metal Finishing 51: 108-112.

Fatah, M.C., Ismail, M.C. \& Wahjoedi, B.A. 2013. Effects of sulphide ion on corrosion behaviour of X52 steel in simulated solution containing metabolic products species: A study pertaining to microbiologically influenced corrosion. Corrosion Engineering Science and Technology 48(3): 211220.

Fonseca, I.T.E., Feio, E., Lino, M.J., Reis, M.A. \& Rainha, V.L. 1997. The influence of the media on the corrosion of mild steel by Desulfovibrio desulfuricans bacteria: An electrochemical study. Eletrochemica Acta 43: 213-222.

Ismail, M., Noor, N.M., Yahaya, N., Bakar, A.A., Ali, M.K.F. \& Abdullah, A. 2015. Statistical investigation on anaerobic sulphate-reducing bacteria growth by turbidity method.
International Journal of Biological Chemistry 9(4): 178187.

Ismail, M., Yahaya, N., Bakar, A.A. \& Noor, N.M. 2014 Cultivation of sulphate reducing bacteria in different media. Malaysian Journal of Civil Engineering 26(3): 456-465.

Jacobson, G.A. 2007. Corrosion at Prudhoe Bay: A lesson on the line. Material Performance 46: 27-34.

Javaherdashti, R. 2008. Microbiologically Influenced Corrosion: An Engineering Insight. London: Springer.

Kakooei, S., Ismail, M.C. \& Ariwahjoedi, B. 2012. Mechanisms of microbiologically influenced corrosion: A review. World Applied Sciences Journal 17(4): 524-531.

King, R.A. \& Miller, J.D.A. 1971. Corrosion by the sulphatereducing bacteria. Nature 233: 491-492

Kirchman, D.L., Malmstrom, R.R. \& Cottrell, M.T. 2005. Control of bacterial growth by temperature and organic matter in the Western Arctic. Deep Sea Research Part II Topical Studies in Oceanography 52(24-26): 3386-3395.

Li, Y., Xu, D., Chen, C., Li, X., Jia, R., Zhang, D., Sand, W., Wang, F. \& Gu, T. 2018. Anaerobic microbiologically influenced corrosion mechanisms interpreted using bioenergetics and bioelectrochemistry: A review. Journal of Materials Science and Technology 34: 1713-1718.

Lv, L., Zhou, L., Wang, L.Y., Liu, J.F., Gu, J.D., Mu, B.Z. \& Yang, S.Z. 2016. Selective inhibition of methanogenesis by sulfate in enrichment culture with production water from low-temperature oil reservoir. International Biodeterioration \& Biodegradation 108: 133-141.

Mataqi, K.Y. \& Akbar, B.H. 2013. Sulphur cycle of microbial corrosion on carbon steel in soil model. International Journal of Engineering Research and Applications 3(2): 617-623.

Othman, S.R. 2015. Modelling of external corrosion growth of steel pipeline in soil for tropical climate. $\mathrm{PhD}$ Thesis. Universiti Teknologi Malaysia (Unpublished).

Rabus, R., Hansen, T.A. \& Widdel, F. 2006. Dissimilatory sulfateand sulfur reducing prokaryotes. In The Prokaryotes, edited by Dworkin, M., Falkow, S., Rosenberg, E., Schleifer, K.H. \& Stackebrandt, E. 3rd ed. Volume 2. Singapore: Springer Science.

Sahrani, F.K., Zaharah, I., Adibah, Y. \& Madzlan, A. 2008. Isolation and identification of marine sulpahte-reducing bacteria, Desulfovibrio sp. and Citrobacter Freundii from Pasir Gudang, Malaysia. Sains Malaysiana 37(4): 365-371.

Santegoeds, C.M., Ferdelman, T.G., Muyzer, G. \& Beer, D.D. 1998. Structural and functional dynamics of sulfatereducing populations in bacterial biofilms. Applied and Environmental Microbiology 64(10): 3731-3739.

Strickland, L., Fortnum, R. \& Bose, B.D. 1996. A case history of microbiologically influenced corrosion in the Lost Hills Oilfield, Kern County, California. Paper No. 297: The NACE International Annual Conference and Exposition. pp. 1-20.

Stott, J.F.D. 2003. Evaluating microbiologically influenced corrosion. In Corrosion Fundamentals, Testing and Protection. ASM Handbook, USA: ASM International, 13A. pp. 644-649.

Sukla, L.B. \& Misra, V.N. 2002. Mineral Biotechnology. Solar Energy Society of India (SESI). p. 30.

Truong, V.K., Lapovok, R., Estrin, Y.S., Rundell, S. \& Wang, J.Y. 2010. The influence of nano-scale surface roughness on bacterial adhesion to ultrafine-grained titanium. Biomaterials 31: 3674-3683.

Varjani, S.J. \& Upasani, V.N. 2017. Crude oil degradation by Pseudomonas aeruginosa NCIM 5514: Influence of process 
parameters. Indian Journal of Experimental Biology 55: 493-497.

Videla, H.A. \& Herrera, L.K. 2005. Microbiologically influenced corrosion: Looking to the future. International Microbiology 8(3): 169-180.

Wang, G., Spencer, J. \& Elsayed, T. 2003. Estimation of corrosion rates of structural members in oil tankers. Proceeding of OMAE 2003. 22nd International Conference on Offshore Mechanics and Arctic Engineering. pp. 1-6.

White, C. \& Gadd, G.M. 1996. Mixed sulphate-reducing bacterial cultures for bioprecipitation of toxic metals: Factorial and response-surface analysis of the effects of dilution rate, sulphate and substrate concentration. Microbiology 142: 2197-2205.

Xu, J., Wang, K., Sun, C., Wang, F., Li, X., Yang, J. \& Yu, C. 2011. The effect of sulfate reducing bacteria on corrosion of carbon steel Q235 under stimulated disbonded coating by using electrochemical impedance spectroscopy. Corrosion Science 53: 1554-1562.

Xu, D. \& Gu, T. 2011. Bioenergetics explains when and why more severe MIC pitting by SRB can occur. In NACE International: Corrosion 2011 Conference \& Expo. pp. $1-21$.
Zhang, C., Wen, F. \& Cao, Y. 2011. Progress in research of corrosion and protection by sulfate reducing bacteria. Procedia Environmental Science 10: 1177-1182.

Muhammad Khairool Fahmy Mohd Ali, Mardhiah Ismail, Akrima Abu Bakar, Norhazilan Md. Noor, Nordin Yahaya, Libriati Zardasti* \& Abdul Rahman Md. Sam

School of Civil Engineering

Faculty of Engineering

Universiti Teknologi Malaysia

81310 Johor Bahru, Johor Darul Takzim

Malaysia

Norhazilan Md. Noor \& Abdul Rahman Md. Sam

Construction Research Centre

School of Civil Engineering

Faculty of Engineering

Universiti Teknologi Malaysia

81310 Johor Bahru, Johor Darul Takzim

Malaysia

*Corresponding author; email: libriati@utm.my

Received: 20 June 2019

Accepted: 4 December 2019 